Station Huspital, Aden; Surgeon.Captain T. M Curker to the Sration Huspital, Hyderabdd; Surgeon-Captain H. J. Wyath to the Puona District.

The retirements on temporary half.pay on account of illhealth of the undermentioned Surgeon-Captains are postdated as follows:-John Lees Hall, to Sept. 3rd, 1891, Vere Elward Hanter. to Jane $29 \mathrm{rh}, 1891$, and Whitley Bland Stokes, M.B., F.R.C.S I., to March 2nd, 1890. - The Queen has approved of the resignation of the Servlce by 1he undermentioned Officer: Surgeon-Captain Herbert William George Macleod, Bingal Medical Establishment (dated April 25th, 1892).

Yeomanry Cavalry. - Northumberland (Husars): Arohur Bramell, Gent., to be Sargeon-Lieutenant (dated May 21st, 1892).

\section{Indian Medrcal, Service.}

We regret to announce the denth of Brigade-Surgeon Wm. Dymock, retired Medical Storekeeper, with the Bombay Government. Doceased was at one time connected with the European General Hospital. He held the post of Medical Sborekeeper from 1870 vo 1890 . In addition to his duties as $M \pm d i c a l$ S sorekeeper, the late cificer held the post of Professor of Materia Meáica in the Grunt Medical College. He was well versed in Arabic and Persian langnages, and was the author of the "Pharmacographia Indica.'

The civil hospital assistants in the Punjzb have memorialised the Surgeon-General with the Government of India, praying for an improvement of their emoluments and status, on the lines sanctioned for the milibary branch of hospital assistants.

Madras General Orders.-Surgeon-Maj r A. H. Laapingwell, Districo Sargeon, Malabar, and Saperintendent of Gaol, Calicut, is appointed to act as District Surgeon and Superintendent of Gasl, Vizagapatam, during the absence of Surgeon-Major Lionel Beech on leave-Mr. C. A. Lafienais, Assistant Surgeon, Malabar, is appointed to act as District Surgeon, Malabar, and Superintendent of Gaol, Calicut, as a temporary arrangement, during the employment of Surgeon-Major Leapingwell on other duty.-Surgeon-Major '. H. Pupe, M.D., Acting Chemical Examiner to Government, is appointed to aco as Superintendent, Ophthalmic Hospital, Madras, during the absence of Brigade-SurgeonJieatenant-Colonel E. F. Drake-Brockman. - SurgeonCaptain F. J. Crawford, M.D., Second Surgeon, General Hospibal, is appointed to act as Secretary to the SargeonGeneral with the Government of Mudras, during the absence of Surgeon-Major C. M. Thompson, M.B., on leave - Surgeon.Captain A. T. Lodgepatch, M.B., Acting Civil Surgeon, Cusonada, is appointed to act as Civil Surgeon, Cannanore, duriag the emplovment of Surgeon-Major S. C. Sarkies on other duty. - The Commander-in-Chief is pleased to direct the following postings:-Brigade-Surgeon.Lieutenant.Culonel G. Andrew, M. B., in medical charge of the North Snation Hospital, Bangalore, to the medical charge of the Soath Station Hospital, Secunderabad; Surgeon-Major G. D. Buarke, in medical charge of the Suath Station Hospital, Secunderabad, to the medical charge of the Central Station Hospital, Sacunderabad, - Sargeon-Lieutenant W. C. Sprague, M.D., has been brought on the strength of the Bumbay Medical Establishment from the 23rd nlt, the date of his arrival at Bimbay- - Surgeon-LieutenantColonel W. MeConaghy, M.D., Indian Medical Service, and Major H. C. E. Luçs, Indian Sbaff Corps, have been permibted by the Se:ratary of Sbate for India to return to duby. - Surgeon-Capbain A. Street, Indian Medical Service (in medical charge of the No. 5 Bombay Mountain Battery), left Poona en route for Neemuch on the 22nd ult., to take over the medical charge of the $26 \mathrm{sh}$ Bombay Infantry. - The services of Surgeon Captain M. B. Braganza, Indian Medical Service, $24 \mathrm{gh}$ Bombay Infantry, have been replaced at the disposal of the Military Department, from Feb. 18bb, on which date he was relieved of his udties as Officiating Medical Officer of the 2nd Regiment Central Indiat Horse and of the Western Malwa Political Agency.

Naval Medical Service. - The following appointment has been made at the Admiralty:-Deputy-InspectorGeneral of Hospitals and Fleets Duncan Hilston, M D., has been promoted to the rank of Inspector.General of Hospibals and Fleets in Her Majesty's Fleet (dated Miy 7th, 1892).

\section{Correspondence.}

\author{
"Audi alteram partem."
}

\section{"THE DEBATE ON RENAL DROPSY."} To the Editors of THE LANCET.

SIRS,-Your leading article of last week on the debate ab the Medical and Chirurgical Society on Renal Dropsy makes it necessary for me to correct one expression which fell from me which was far from conveying niy meaning. $I$ am represented as thanking Dr. Broanbent for supporting, no $)$ myself, but the truth. Far be it from me to presume that those who think with me therefore think right. What was in my mind to say-and I regret that my haste or awkwarduess of speech prevented my saying it clearly - was that I recognised in Dr. Broadbent, not a desire to supporb myself personally, but to support what he thought to be true, and claimed for myself the same alm as supreme above personal contention. I had been careful even to iteration to say that there was no finality in an explanation which had heen suggested; that some of the questions before the Suciety were difficult and complicated; that further help from physlologists was needed. I do not claim to be the exponent of truth, but only a seeker for it. With what modicum of success this search has been attended I should shrink from expressing an opinion, which would certainly be blased, and not improbably erroneous.

I am glad to take this opportunity of disclaiming an arrogance as foreign to my intention as inconsistent with my sense of propriety. $-\mathrm{I} 2 \mathrm{~m}$, Sirs, yours truly, May 25th, 1892.

W. HowsHIP DICKINSON.

\section{INCREASE OF SMALL-POX AND THE INTERIM REPORT OF THE VACCINATION COMMISSION.}

\section{To the Editors of THH LANCET.}

SiRs, - The two letters on the above subjects in your issue of the 21 st inst. are fraught with matter of the greatest importance to the future of this densely populated constry, and I brusó you will allow me to briefly allude to it. With reference to the first, I have libtle doubt that when the force of the small-pox contagion rises, the vast amount of inefficient vaccination, as evinced by the last small-pox epidemic ay Sheffield, will be terrlbly manifested and with regard to the second, the isolation and destruction of propagating influences in places like Leicester will be severely tested, as the present protection of that city is largely due to the amount of even the partially efficient vaccination around it, redueing the points of attack to a manageable number. This interim report, however, of the Vaccination Commission, if carried out, must lead to the complete fallure of the methods now employed at Leicester to limit the small-pox contagion, as year by year the numbers of unvaccinated. cases around the city will increase ; for within a few months of the suggestions of the Vaccination Commission becoming law, anti-vaccination insurance societies will spring up, which for a very small monthly payment will readily provide the arnount of the fine imposed, and as these penalties are no' to be cumulative, the case will, of course, remain " unvaccinabed." I was quite prepared for this decision of the Vaccination Commission, as the practical failure of vaccination at Sheffield and the success of isola. tion at Lsicester must have had $a_{\text {s }}$ greab effect on many of the members composing the Commission, and, doubtless, led some to ask, Why continue fining those who persistently reject vaccination, when their system of probection, when judged by results, seems so superior to that which cost so much in rewards alone at Sheffield, and yet failed so signally, and that in the case of a ciby whose manufactures-iron and steel-are least of all capable of retaining or propagating the small-pox infection. Here, perhaps, I may allude to a strange anomaly witnessed in the mode of conducting inquiries in the failure of various systems when danger to life is incurred. In $\mathrm{mv}$ paper, read at the Epidemiological Socleby of London this year, entitled "What is Efficient Vaccination?" I ask a 
question which ere long will have to be answered-viz., Why should an inquiry into the causes of failure in the management of a railway system-by which risk to, it may be loss of, life is incurred-be conducted by an officer of the Royal Engineers, and not by one of the civil engineers of the company, when the investigation into a failure in a system of vaccination, like that witnessed in the late smallpox epidemic at Sheffield, was carried out by a departmental officer, on whom was laid the invidious task of finding faults in a system so admirable in ibs execution that, in the opinion of those in the department best able to judge, it received in ten years more than $£ 1000$ in rewards?

I am, Sirs, yours faithfully,

Robert Pringle, M.D., Brigade Surgeon.

Blackheath, S.E., May 23rd, 1892

\section{DEATH UNDER CHLOROFORM. \\ To the Editors of THE LANCET.}

SIRS, - Upon reading the account of the case reported by Dr. Colvin Smith, one cannot help thinking whether the result would have been different if some brandy had been given before the inhalation was commenced. We direct a patient not to take food for some hours previously to the administration of an anæsthetic, but do we always suffi. ciently take into account the effect produced by the fasting? In the case mentioned we have a pale, anæmic child, aged eleven, who breakfasted at 7.30 A.M. (and perhaps did not take much), had to walk to the hospital, and, nearly six hours after his early meal, was operated on. The first meal of the day we know is rapidly absorbed, and, by eleven or twelve o'clock, in many who breakfast early, a feeling akin to exhaustion arises. Then, again, do we sufficiently consider the amount of shock which an operation causes, even when the pain is prevented by narcotism? A death under chloroform is so terrible to all concerned, that we ought not to think anything too trivial to attend to which might possibly be of use in averting such an accident. Dr. Colvin Smith will, I am sure, understand that I am only suggesting queries to thinking minds, and that $I$ am not in any way desirous of acting as a censor. Notwithstanding the Hyderabad Commission, I feel perfectly certain (having extremely good reason for saying so) that the pulse ought to be carefully watched in every case.

I am, Sirs, yours truly,

South Hampstead, N.W., May 24th, 1892

R. H. Milson, M.D.

\section{To the Editors of THE LANCET.}

SIRS, - In your issue of May 2 lst there is the report of a death under chloroform at the Victoria Hospital, Chelsea. When we consider the circumstances of the case, I for one am not surprised that the boy died of syncope. It is stated that a boy of eleven was told to have breakfast at 7.30 A. .r. and to eat nothing afterwards. Now, a boy of that age would probably have supper at 7 o'clock on the previous evening, and be put to bed about 8 o'clock. Getting up about 7, he had breakfast at 7.30. He was probably told to have a light one. Being an out-patient, he walked to the hospital, perhaps some distance off, waited there some weary hours, and was not operated upon until 1.15 P.M.-i.e., five hours and three-quarters after his last meal, and only one meal for eighteen hours and a quarter. Leaving out of consideration his state of nervous excitement, the posr little man must have been in almost a condition of starvation. For several years I have considered three and a half or four hours quite long enough after a meal to give an anosthetic.

I am, Sirs, yours truly,

PIymouth, May 24th, 1892. J. ELLIOT SqUARE, F.R.C.S.

\section{I D I F E R S TA T IST I C S. To the Ealitors of THE IAANCET.}

SIRs,-Under the heading "Startling Figures from a Doctor," a statement attributed to Dr. Rentoul of Liverpool appeared in the lay press in the latter part or last week, to the effect that "one in every fifteen first labour cases resulted in the death of the woman." Such an assertion may well be described as "startling," and if uttered by Dr. Rentoul it would be interesting to know the source of his information, as it does not agree with the experlence gained by connexion with lying-in charities. Speaking more particularly of the City of London Lying-in Hospital, with which I have been connected for the past twenty years, the records furnish the following facts :- Since the establishment of an out-door department in 1872 20.631 women have been attended at their own homes by the midwives and pupils abtached to the hospital. Of this number 45 have died, being at the rate of $2 \cdot 13$ per 1000 . I regret I am unable to say how many of these were first labours. Since July, 1886, however, I have been in cbarge of the in-door department, and during this perlod 2393 women have been delivered in the hospital, of whom eight died. The number of primiparæ was 590, and of these three died, and I have no doubt that other lying-in charities can furnish similar results. I am, Sirs, yours truly,

G. E. YARROW

Surgeon-Accoucheur to the City of London Hospital.

May, 25th, 1892 .

\section{"THE LONDON AND COUNTIES MEDICAL PROTECTION SOCIETY, LTMITED,"}

\section{To the Editors of THE LANCET.}

SrRs,-Having recently been the subject of annoyance and perhaps injury, I can readily bear testimony to the great value of combined support of my professional brethren. I will not trouble you with the devails of my case, which brought to the notice of the medical profession on public grounds; but I do feel I owe a deep deby of gratitude to many members of the profession, more particularly to $\mathrm{Dr}$. Mead, Dr. Balding, and Dr. Grove, who spared neither time nor trouble to help me at a time when help and sympathy were invaluable, and I feel that had there not been friends like them I should never have obtained that triumphant vindication I did from the medical and local press. The able speeches of the chairman (Dr. Balding, J.P.) at the Cambridge meetings, and those of Dr. Latham, Dr. Beekett, Dr. Grove, and others, I much regret did not appear in print in the local press, as they would have been both valuable from a scientific point of view, as illustrating the difficulties in which medical men are often placed with respect to the stringent and little-known laws now in force in sanitary matters, and also as an enlightenment to boards of guardians and the public generally on questions of sanitary science.

I am glad to find the efficiency of this mode of combination for the professional good is likely to be rendered more efficient by the London and Counties Medical Protection Society (Limited). I am certain all members of the profession will feel that the interests of the humblest as well as the most highly placed will be safe in the hands of such men as Mr. Jonathan Hutchinson, F R.S., Dr. G. A. Heron, F. R.C.P., and Dr. Mead. I have had the greatest pleasure in joining this Society, and in getting many of $\mathrm{my}$ friends to do the same. I have carefully examined the plan of organisation and fully approve of it. The system of local councils secures the least known from being passed over The right of appeal in the first instance, if the aggrieved member wishes it, to the central council, or from the decisiou of the losal council to the central council if he be dis. satisfied, must commend itself to every lover of fair play, especially as there are on the conncil some of the best men of the day. I remain, Sirs, yours truly,

Brandon, May 23rd, 1892. C. M. FEGEN.

\section{MANCHESTER.}

(FroM OUR OWN CORRESPONDENT.)

\section{The Hospital for Consumption and Diseases of the Throat.}

THE in-patient department of this hospital is at Bowdon, Cheshire, some eight miles from Manchester. A new outpatient department in the centre of the city was recently opened, ard at the time an appeal was made for further subscriptions, to enable the committee to open more beds at their Bowdon Hospital. It appears, however, from a letter written by the chairman and the treasurer, that, only about $£ 30$ have been subscribed as a result of this appeal, and those gentlemen fear that, so far from opening new beds, some of those now open may have to be closed, as the institution has been getting into debt. It is much to be regretted thet the public show so little practical interest in this matter. 